This is the author's final, peer-reviewed manuscript as accepted for publication. The publisher-formatted version may be available through the publisher's web site or your institution's library.

\title{
Titanium-indium oxy(nitride) with and without RuO2 loading as photocatalysts for hydrogen production under visible light from water
}

Yenting Kuo, Clint D. Frye, Myles Ikenberry and Kenneth J. Klabunde

\section{How to cite this manuscript}

If you make reference to this version of the manuscript, use the following information:

Kuo, Y., Frye, C. D., Ikenberry, M., \& Klabunde, K. J. (2013). Titanium-indium oxy(nitride) with and without RuO2 loading as photocatalysts for hydrogen production under visible light from water. Retrieved from http://krex.ksu.edu

\section{Published Version Information}

Citation: Kuo, Y., Frye, C. D., Ikenberry, M., \& Klabunde, K. J. (2013). Titanium-indium oxy(nitride) with and without RuO2 loading as photocatalysts for hydrogen production under visible light from water. Catalysis Today, 199, 15-21.

Copyright: () 2012 Elsevier B.V.

Digital Object Identifier (DOI): doi:10.1016/j.cattod.2012.03.012

Publisher's Link: http://www.sciencedirect.com/science/article/pii/S0920586112001630

This item was retrieved from the K-State Research Exchange (K-REx), the institutional repository of Kansas State University. K-REx is available at http://krex.ksu.edu 
Titanium-Indium Oxy(nitride) with and without $\mathrm{RuO}_{2}$ loading as Photocatalysts for Hydrogen Production under Visible Light from Water

\author{
Yenting Kuo $^{a}$, Clint D. Frye ${ }^{b}$, Myles Ikenberry ${ }^{c}$ and Kenneth J. Klabunde ${ }^{* a}$ \\ ${ }^{a}$ Department of Chemistry, Kansas State University, KS, 66506, USA \\ ${ }^{\mathrm{b}}$ Department of Chemical Engineering, University of Kansas, KS, 66045, USA \\ ${ }^{\mathrm{c}}$ Department of Chemical Engineering, Kansas State University, KS, 66506, USA
}

Corresponding author: - Fax +1-785-532-6666

Email address: kenjk@ksu.edu (K. J. Klabunde) 


\begin{abstract}
Titanium-indium (oxy)nitride composite materials with and without $\mathrm{RuO}_{2}$ loadings were produced by treating $\mathrm{TiO}_{2}-\mathrm{In}_{2} \mathrm{O}_{3}$ mixed powders with ammonia at high temperature (700-850 ${ }^{\circ} \mathrm{C}$ ) (Elemental analysis indicated an empirical formula of $\operatorname{Ti}_{0.029} \mathrm{O}_{0.63} \mathrm{~N}_{1.4}$ ).

We have found that ammonolysis of $\mathrm{TiO}_{2}$ to form $\mathrm{Ti}$ (oxy)nitride or $\mathrm{In}_{2} \mathrm{O}_{3}$ to form $\mathrm{In}$ (oxy)nitride do not give composites active toward methanol-water under visible light, but $\mathrm{TiO}_{2}$ and $\mathrm{In}_{2} \mathrm{O}_{3}$ mixed together $\underline{\text { do }}$ give composites active toward methanol-water under visible light. Ti-In (oxy)nitride powders modified by surface loading with $\mathrm{RuO}_{2}$ nanoparticles at 3 wt $\%$ achieves the highest $\mathrm{H}_{2}$ evolution activity under visible light irradiation. The composite material did not react in the dark, but upon irradiation with visible light, the hydrogen production rate under illumination goes way up to $30 \mu \mathrm{mole} \cdot \mathrm{h}^{-}$ ${ }^{1}$ and the turnover number shows that this is a photocatalytic reaction.
\end{abstract}

\title{
Graphical abstract
}

\section{Photocatalytic $\mathrm{H}_{2}$ evolution test}
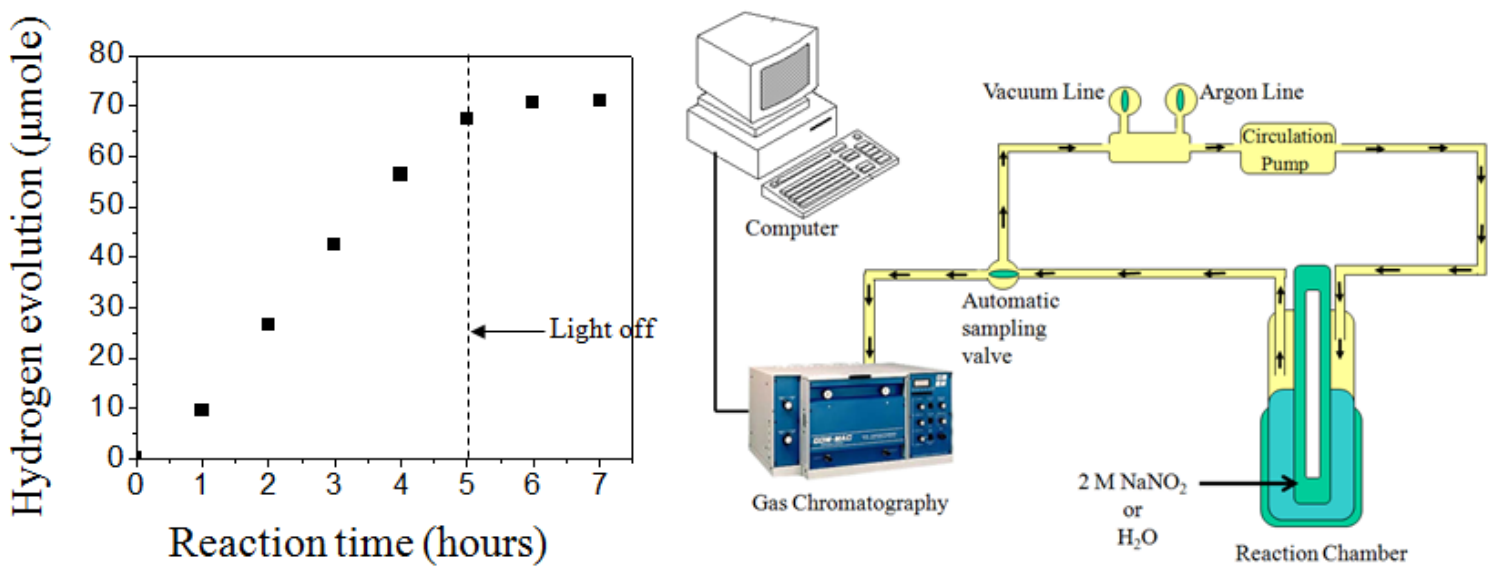


\section{Highlights}

- Titanium-Indium Oxy(nitride) with and without $\mathrm{RuO}_{2}$ loading as Photocatalysts were investigated. $3 \mathrm{wt} \% \mathrm{RuO}_{2}$-loaded Ti-In oxy(nitride) composites showed higher catalytic performance than the other photocatalysts. The XPS data shows $\mathrm{Ti}^{4+}$ could be reduced to $3+$ and $2+$ upon ammonia treatment with $\mathrm{In}_{2} \mathrm{O}_{3}$ presence. - It was found that the treatment temperature increased from 750 to $850{ }^{\circ} \mathrm{C}$, the composites began to aggregate because of growth of the $\mathrm{TiO}_{2}$ (anatase).

Keywords: $\mathrm{H}_{2}$ evolution; Photocatalysts; $\mathrm{Ru}$ co-catalyst; Titanium Dioxide; Indium Oixde

\section{Article Outline}

1. Introduction

2. Experimental

2.1. Preparation of Ti-In nitride composites with and without $\mathrm{RuO}_{2}$

2.2. Photocatalytic activity

2.3. Characterization of composites

3. Results and Discussion

3.1. Characterization of Ti-In oxy(nitride) composites

3.2. Photocatalytic activity of Ti-In oxy(nitride) composites

3.3. Photocatalytic activity of $\mathrm{RuO}_{2}$-loaded Ti-In oxy(nitride) composites

4. Conclusions

Acknowledgements

References

\section{Introduction}


Osterloh[1] has recently reviewed inorganic materials for photochemical water splitting. Over 130 inorganic materials/composites are mentioned. Metal nitrides and metal-oxynitride composites have also received some study, such as $\beta-\mathrm{Ge}_{3} \mathrm{~N}_{4}$ and $\mathrm{GaN}: \mathrm{ZnO}$ solid solution prepared from commercially available $\mathrm{GeO}_{2}$ powder or a mixture of $\mathrm{Ga}_{2} \mathrm{O}_{3}$ and $\mathrm{ZnO}$ by nitridation under atmospheric $\mathrm{NH}_{3}$ flow, respectively, and loaded with $\mathrm{RuO}_{2}$ as co-catalyst.[2, 3] These studies revealed that the photocatalytic activity for water splitting depends on the crystallinity and composition of the material. Moreover, evidence shows that using nitrogen to replace Oxygen in $\mathrm{TiO}_{2}$ to form $\mathrm{TiO}_{2}$ ${ }_{x} \mathrm{~N}_{\mathrm{x}}$ can enhance photocatalytic activities under visible light. [4, 5]

Additionally, Poznyak and co-workers have investigated the photoelectrochemical properties of nanocrystalline $\mathrm{TiO}_{2} / \mathrm{In}_{2} \mathrm{O}_{3}$ composite solids.[6] It was shown that $\mathrm{TiO}_{2} / \mathrm{In}_{2} \mathrm{O}_{3}$ composites allow efficient separation of photogenerated charge carriers occurring in interconnected $\mathrm{TiO}_{2}$ and $\mathrm{In}_{2} \mathrm{O}_{3}$ particles, owing to the favorable energetics of the conduction bands of these oxides. Another report shows that nitrogen-doped $\operatorname{In}_{2} \mathrm{O}_{3}$ thin film electrodes are effective for photocatalytic water splitting.[7] Therefore, it may be possible to combine the $\mathrm{TiO}_{2}$ property of formation of electrons and holes by absorbing light and then using the interconnection between $\mathrm{TiO}_{2}$ and $\mathrm{In}_{2} \mathrm{O}_{3}$ to transfer the holes to $\mathrm{In}_{2} \mathrm{O}_{3}$. Moreover, the nitrided treatment of a mixture of titanium oxide and indium oxide may be effective to enhance absorption of visible light. In our research, optimal preparation conditions were investigated in order to achieve the best hydrogen production under visible light. Reported herein are our results with methanol-water solutions. 


\section{Experimental}

\subsection{Preparation of Ti-In nitride composites with and without $\mathrm{RuO}_{2}$}

Composite powders were prepared by heating a mixture of $0.92 \mathrm{~g}\left(1.2 \times 10^{-2} \mathrm{~mol}\right)$ anatase $\mathrm{TiO}_{2}$ powder (Sigma-Aldrich, anatase, nanopowder, $<25 \mathrm{~nm}, 99.7 \%$ ) and $3.2 \mathrm{~g}$ $\left(1.2 \times 10^{-2} \mathrm{~mol}\right) \mathrm{In}_{2} \mathrm{O}_{3}$ powder (Sigma-Aldrich, nanopowder, $\left.<100 \mathrm{~nm}, 99.9 \%\right)$ at different temperatures under $\mathrm{NH}_{3}$ flow $(250 \mathrm{~mL} / \mathrm{min}$ ) for 20 hours as shown in Fig. 1 (The reaction chamber diameter is $4.5 \mathrm{~cm})$. The mole ratio of Ti to $\mathrm{In}$ in the starting material $\left(\mathrm{TiO}_{2}\right.$ and $\mathrm{In}_{2} \mathrm{O}_{3}$ ) was $1 / 1$, which should give a Ti:In ratio of 1:2 (although, in reality, much of the indium was lost during the ammonia treatment; see later discussion). After 20 hours of ammonolysis, the sample was cooled to room temperature under $\mathrm{NH}_{3}$ flow.

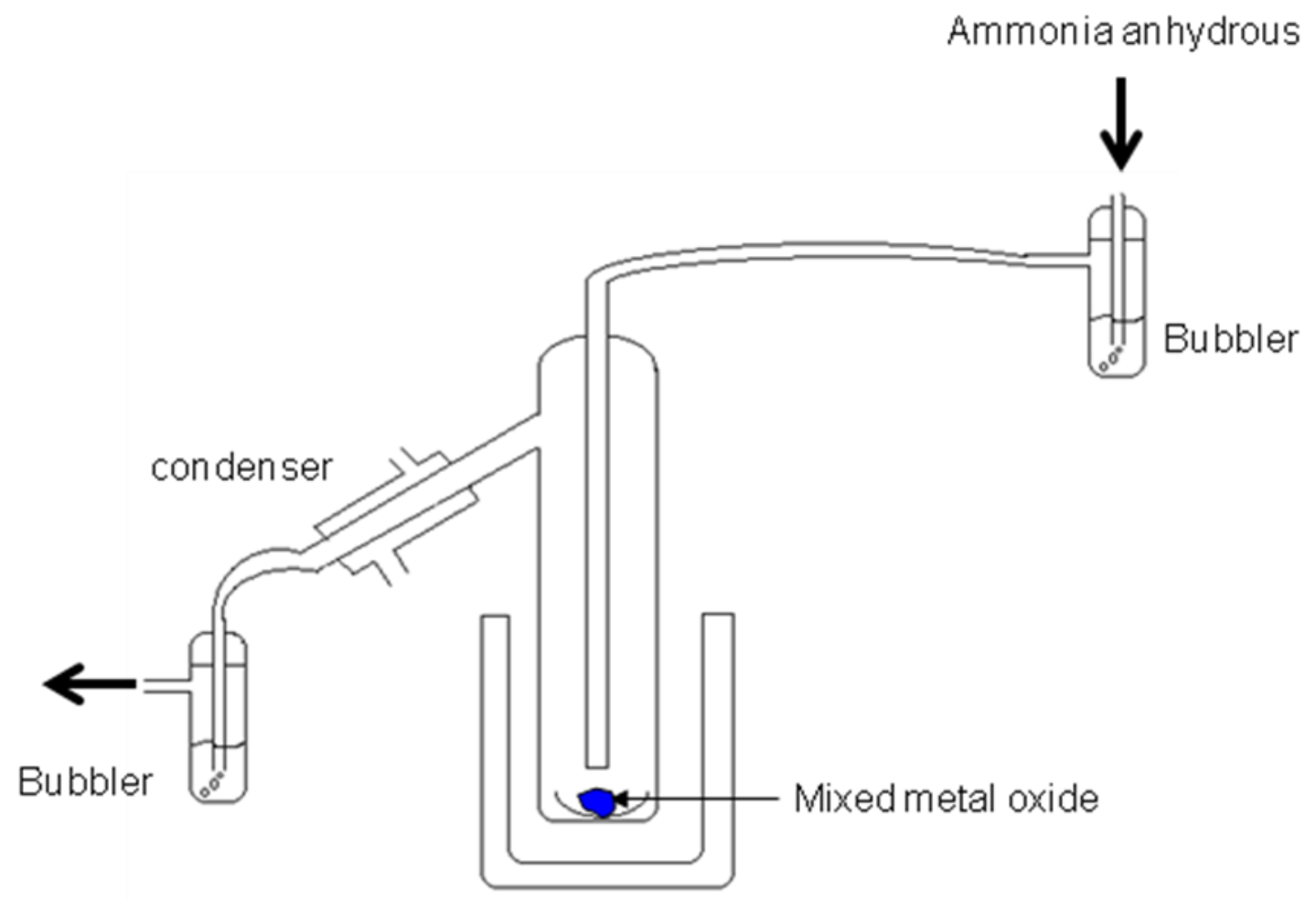

Fig. 1. Experimental setup for nitridation of $\mathrm{TiO}_{2} / \mathrm{In}_{2} \mathrm{O}_{3}$ mixture. 
$\mathrm{RuO}_{2}$ was loaded onto the as-prepared Ti-In nitride powders as a co-catalyst by immersing the Ti-In nitride composite powders in a tetrahydrofuran (THF) solution containing dissolved ruthenium(III) acetylacetonate (purum, $\geq 97.0 \%(\mathrm{CH})$, Fluka) and stirring. The solution was then dried under air by heating in air at $80{ }^{\circ} \mathrm{C}$ to remove THF. The obtained powders were finally annealed in air at $400{ }^{\circ} \mathrm{C}$ for $4 \mathrm{~h}$.

\subsection{Photocatalytic activity}

The reactions were carried out in a glass-enclosed reaction chamber connected to a gas circulation and evacuation system with a quartz inner irradiation-type reaction vessel.[8] The apparatus contained $345 \mathrm{ml} 10$ vol\% methanol-water solution with $0.13 \mathrm{~g}$ sulfuric acid and $0.30 \mathrm{~g}$ of the composite $\mathrm{RuO}_{2}$-loaded Ti-In (oxy)nitride. The reactant solution was evacuated and filled with argon three times to remove air completely, followed by irradiation $(\lambda>400 \mathrm{~nm}$ ) under a $450 \mathrm{~W}$ high-pressure $\mathrm{Hg}$ lamp via a quartz tube that was air filled for full spectrum UV-vis studies, or filled with $2 \mathrm{M} \mathrm{NaNO}_{2}$ aqueous solution for visible light studies.[3] The reaction temperature was controlled between 20 to $25{ }^{\circ} \mathrm{C}$. $\mathrm{H}_{2}$ production was monitored during the reaction with an online GC system (GOMAC model) employing a Supelco molecular 80/100 sieve 5A column with Ar as the carrier gas and a thermal conductivity detector (TCD).

\subsection{Characterization of composites}

The prepared samples were studied by powder X-ray diffraction (XRD; Bruker D8 Xray diffractometer with $\mathrm{Cu} \mathrm{K} \alpha$ radiation), scanning electron microscopy (SEM; Hitachi S-3500 N), UV-visible diffuse reflectance spectroscopy (DRS; Varian Cary 500 Scan). 
The Brunauer, Emmett, Teller (BET) surface area was measured with a Quantachrome NOVA-1200 instrument at liquid nitrogen temperature. X-ray photoelectron spectroscopy (XPS) was conducted using a SPECS Sage100 spectrometer operating in the fixed analyzer transmission mode using achromatic $\mathrm{Mg} \mathrm{K \alpha}(1253.6 \mathrm{eV})$ radiation at $240 \mathrm{~W}(12$ $\mathrm{kV}$ and $20 \mathrm{~mA}$ ) using a water-cooled X-ray gun cap and evacuated with turbomolecular pumping. The base pressure of the chamber was about $2 \times 10^{-8}$ Torr, and the energy scales were calibrated using copper and the separation between photoelectron peaks generated by $\mathrm{Mg}$ and $\mathrm{Al} \mathrm{K \alpha} \mathrm{X}$-rays. Survey spectra were collected with a pass energy of $30 \mathrm{eV}$; a pass energy of $15 \mathrm{eV}$ was used for both core and valence band spectra. Many of the spectra were calibrated by taking the $\mathrm{C} 1 \mathrm{~s}$ peak due to residual hydrocarbon as being at $284.4 \mathrm{eV}$.

\section{Results and Discussion}

\subsection{Characterization of Ti-In oxy(nitride) composites}

Fig. 2 shows XRD patterns from samples obtained by nitriding a mixture of $\mathrm{TiO}_{2}$ and $\mathrm{In}_{2} \mathrm{O}_{3}$ at several ammonolysis temperatures. $\mathrm{TiO}_{2}, \mathrm{In}_{2} \mathrm{O}_{3}$ and $\mathrm{TiN}$ data are shown for comparison. All composites' patterns are similar to TiN and the peak assignments are based on the ICSD database. None of the diffraction peaks of starting materials were observed, indicating that the obtained samples were not physical mixtures of $\mathrm{TiO}_{2}$ and $\mathrm{In}_{2} \mathrm{O}_{3}$. The peak around $34^{\circ}$ corresponds to both $\mathrm{InN}$ and In metal. The XRD data demonstrate that an ammonolysis temperature above $850{ }^{\circ} \mathrm{C}$, caused an increase of In metal formation (which was generally lost due to the volatility). It is known that $\operatorname{In}_{2} \mathrm{O}_{3}$ is 
reduced to metallic Indium upon ammonolysis of Indium oxide by anhydrous ammonia

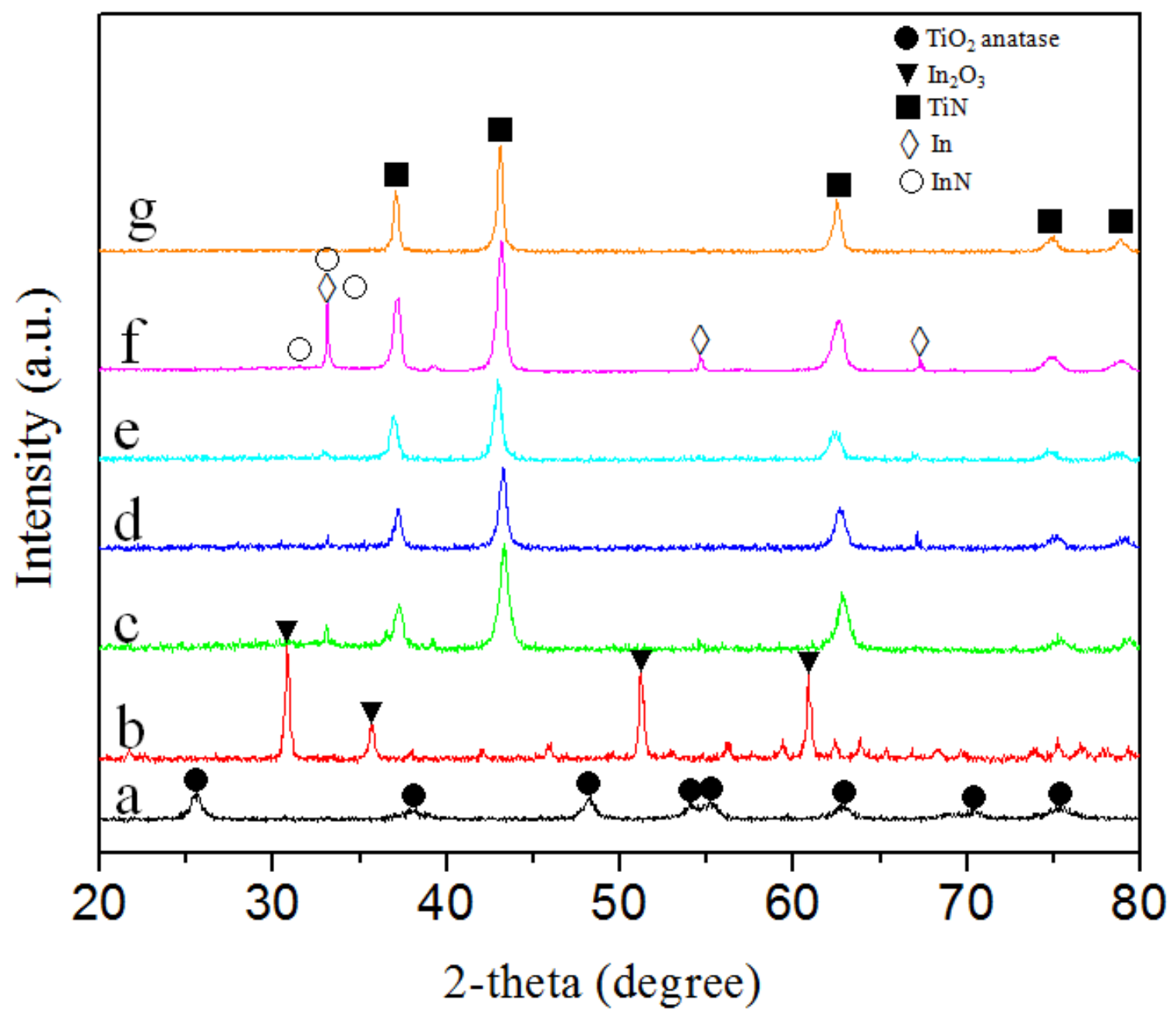

Fig. 2. Powder XRD patterns of Ti-In oxy(nitride) composites obtained by different ammonolysis temperatures samples. (c) $700{ }^{\circ} \mathrm{C}$ (d) $750{ }^{\circ} \mathrm{C}$ (e) $800{ }^{\circ} \mathrm{C}$ (f) $850{ }^{\circ} \mathrm{C}$.

*(a) $\mathrm{TiO}_{2}$ anatase (b) $\mathrm{In}_{2} \mathrm{O}_{3}(\mathrm{~g}) \mathrm{TiN}$ for comparsion.

above $650{ }^{\circ} \mathrm{C}$.[9] Indeed, we found that starting with only $\operatorname{In}_{2} \mathrm{O}_{3}$ and then nitridation, indium metal was produced under the action of hot $\mathrm{NH}_{3}$. The high ammonolysis temperature not only reduced $\mathrm{In}^{3+}$ into $\mathrm{In}$, but also could cause $\mathrm{InN}$ decomposition. Decomposition temperatures reported for $\mathrm{InN}$ range from $500{ }^{\circ} \mathrm{C}$ for thin films $[10,11]$ to $710{ }^{\circ} \mathrm{C}$. In our research, even when the ammonolysis temperature was above $700{ }^{\circ} \mathrm{C}$, 
some InN persisted when $\mathrm{TiO}_{2}$ was also present as a co-reactant. Therefore, combining $\mathrm{TiO}_{2}$ and $\mathrm{In}_{2} \mathrm{O}_{3}$ not only created $\mathrm{H}_{2}$ production activity, but also helped to stabilize InN.

We have examined four areas of the XPS spectra for several samples : the Ti $2 p$ region (466-453 eV), In $3 \mathrm{~d}$ region $(450-454 \mathrm{eV})$, the $\mathrm{O} 1$ s region $(525-537 \mathrm{eV})$, and the $\mathrm{N} 1 \mathrm{~s}$ region (394-400 eV). The survey spectra of all the Ti-In (oxy)nitride powders confirmed the presence of Ti, In, O, N and $\mathrm{C}$. The binding energies (BEs) were calibrated using the C 1s energy of $284.4 \mathrm{eV}$ as an internal calibration.

The Ti $2 \mathrm{p}_{3 / 2}$ has three peaks (Fig. 3A), $458.5 \mathrm{eV}, 457 \mathrm{eV}$ and $455.6 \mathrm{eV}$. Ti $2 \mathrm{p}_{5 / 2}$ has three peaks, $463.9 \mathrm{eV}, 462.5 \mathrm{eV}$ and $461.3 \mathrm{eV}$. They are in agreement with the values reported in the literature for $\mathrm{Ti}^{4+}, \mathrm{Ti}^{3}+$ and $\mathrm{Ti}^{2+}$, respectively. $[9,12]$ The XPS data show that the ammonolysis process can reduce $\mathrm{Ti}^{4+}$ to lower oxidation states. Moreover, the low ammonolysis temperature samples have a higher ratio of $\mathrm{Ti}^{4+}$, which shows the higher ammonia treatment temperature causes more reduction of $\mathrm{Ti}^{4+}$ into $\mathrm{Ti}^{3+}$ or $\mathrm{Ti}^{2+}$. One interesting finding was that there was no $\mathrm{Ti}^{3+}$ and $\mathrm{Ti}^{2+}$ formation when only $\mathrm{TiO}_{2}$ was nitrided by hot $\mathrm{NH}_{3}$. This again, suggests that there is an important synergistic interaction between In and Ti during the nitridation.

As shown in Fig. 3B, The In core spin orbit split to the $3 \mathrm{~d}_{5 / 2}$ peak at $444.5 \mathrm{eV}$. These results are close to the reported values for bulk $\operatorname{InN}(444.3 \mathrm{eV})$. [7, 13] Therefore, XPS further confirms the formation of InN.

Regarding the XPS spectra after photocatalytic reaction, In $3 \mathrm{~d}_{3 / 2}$ XPS spectra (Fig. 3) shows loss of intensity for low ammonolysis temperature samples, which suggests that the lower temperatures yield less stable nitrides. But if the ammonolysis temperature exceeds $850^{\circ} \mathrm{C}$, most of the In was sublimed and lost, and only TiN remained. The 

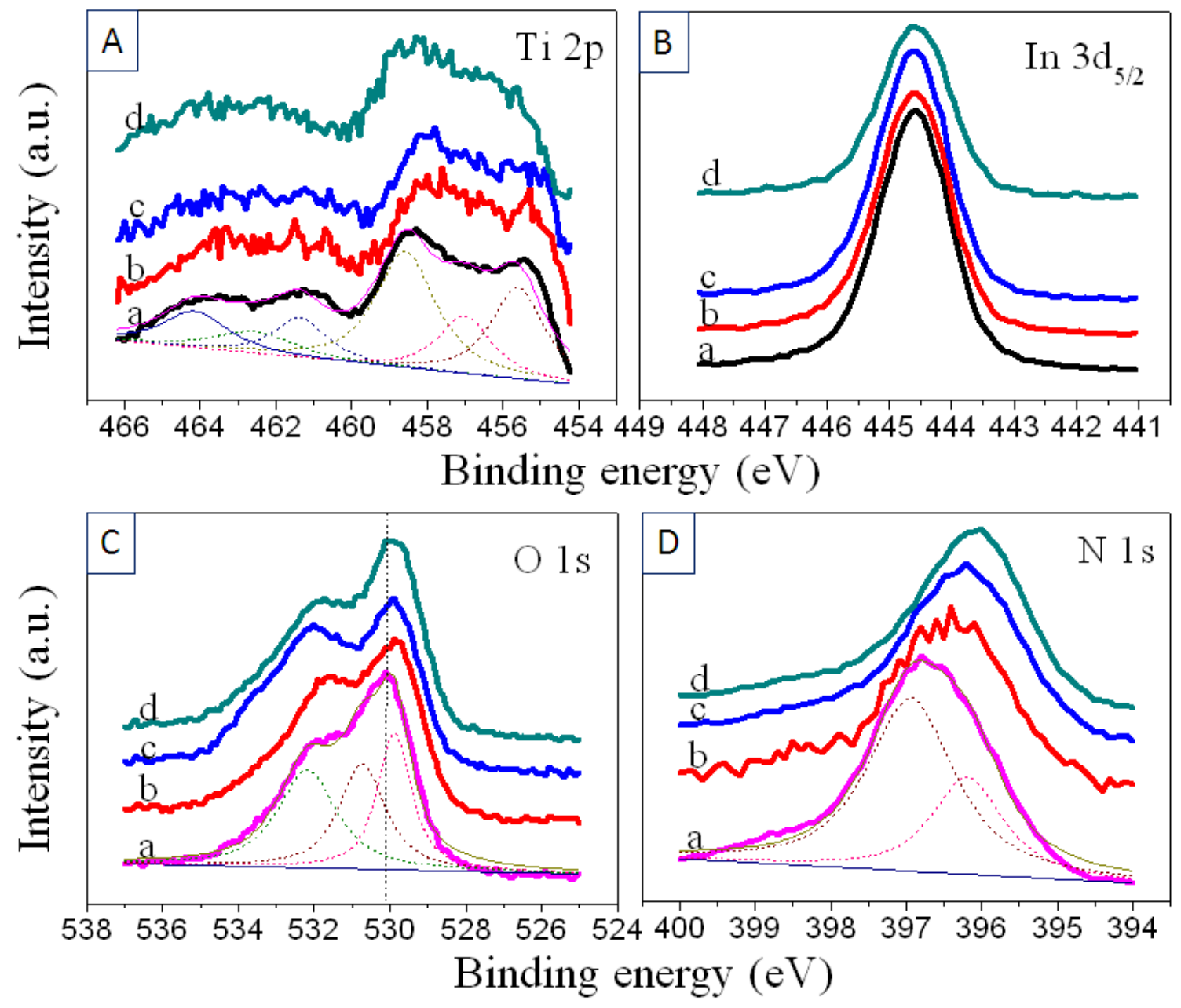

Fig. 3. XPS spectra of Ti-In oxy(nitride) composites obtained by different ammonolysis temperatures. (a) $850{ }^{\circ} \mathrm{C}$ (b) $800{ }^{\circ} \mathrm{C}$ (c) $750{ }^{\circ} \mathrm{C}$ (d) $700{ }^{\circ} \mathrm{C}$.

resulting sample had poor $\mathrm{H}_{2}$ production activity. Therefore, a suitable ammonolysis temperature is very important, which has to be high enough to allow $\mathrm{N}$ doping, but not too high to further reduce $\operatorname{In}^{3+}$ into In metal. All In $3 \mathrm{~d}_{3 / 2}$ XPS spectra (Fig. 3) show the shifting to higher $\mathrm{BE}$ after the reaction, which indicates that some of the doped nitrogen was replaced by oxygen.

Fig. 3C shows that the $\mathrm{O} 1 \mathrm{~s}$ core level is composed of at least three components. The peak positions and intensities are reliably determined by a standard curve fitting procedure using XPSPEAKS software. The $\mathrm{O} 1 \mathrm{~s}$ signal at $529.8 \mathrm{eV}$ is assigned to $\operatorname{In}_{2} \mathrm{O}_{3}$ 
and $\mathrm{TiO}_{2}$ according to the literature,[14] while the signal at $530.8 \mathrm{eV}$ is probably due to oxygen in surface adsorbed hydroxyl groups[15] and the signal at $532.1 \mathrm{eV}$ is from the surface adsorbed $\mathrm{H}_{2} \mathrm{O}$. Low ammonolysis temperature samples show a small shift to lower energy $(529.0 \mathrm{eV})$ for the $\mathrm{O}$ 1s peak that is assigned to $\mathrm{In}_{2} \mathrm{O}_{3}$ and $\mathrm{TiO}_{2}$. This shift is similar to results found for substitutional $\mathrm{N}$-doped $\mathrm{TiO}_{2}$ samples, in which the $\mathrm{P} 25 \mathrm{TiO}_{2}$ sample shows an $\mathrm{O} 1 \mathrm{~s}$ peak at $530.8 \mathrm{eV}$, versus a shift to $530.0 \mathrm{eV}$ that is observed for the nitrogen-doped $\mathrm{TiO}_{2}$ samples.[16]

The N 1s XPS spectrum in Fig. 3D has two components: $396.9 \mathrm{eV}$ and $396.2 \mathrm{eV}$. The $\mathrm{N}$ 1s XPS data confirms the $\mathrm{N}$ is substitutional instead of interstitial. [4, 5, 17] The 396.9 $\mathrm{eV}$ peak could be assigned to Ti-N, and $\mathrm{In}-\mathrm{N}$ is at $396.2 \mathrm{eV}$ because $\mathrm{Ti}$ has a higher electronegativity than In. The XPS high-resolution spectra of $\mathrm{N} 1 \mathrm{~s}$ show the $850{ }^{\circ} \mathrm{C}$ ammonolysis sample's peak at $396.7 \mathrm{eV}$ with a slight shift to $396.1 \mathrm{eV}$ for the $700{ }^{\circ} \mathrm{C}$ sample (Fig. 3D). The difference of $0.6 \mathrm{eV}$ between these two $\mathrm{N}$ 1s peaks correlates with InN formation for the $\mathrm{N} 1 \mathrm{~s}$ state in substitutional sites. Therefore, the data (Fig. 3D) shows more formation of $\mathrm{N}$ in substitutional sites under higher ammonolysis temperature conditions.

\subsection{Photocatalytic activity of Ti-In oxy(nitride) composites}

Fig. 4 shows the hydrogen production activity of a Ti-In oxy(nitride) composite (ammonolysis at $700{ }^{\circ} \mathrm{C}$ ) in 10 vol\% methanol-water solution under visible light. In the dark, there was no activity observed. However, after the light was on, the reaction can be driven by visible light, producing $\sim 0.5 \mu$ mole $\cdot h^{-1} \mathrm{H}_{2}$ gas. The activity stabilized, and 
continued to produce $\mathrm{H}_{2}$ gas for over 200 hours. $\mathrm{H}_{2} \mathrm{SO}_{4}$ was added to adjust solution $\mathrm{pH}$ to acidic condition, the photocatalytic activity was not enhanced.

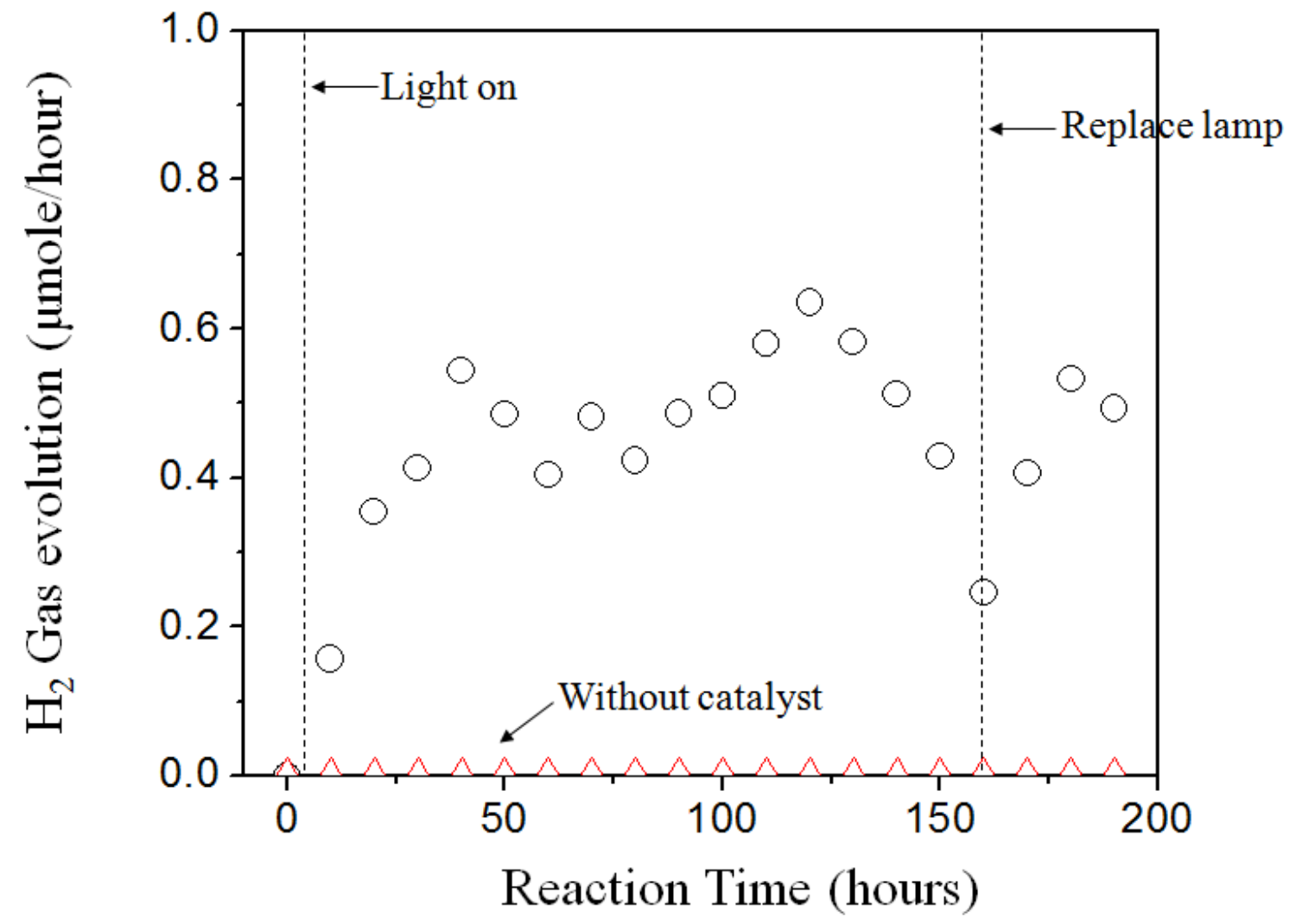

Fig. 4. Dependence of visible light hydrogen production activity of a Ti-In oxy(nitride) composite (ammonolysis at $700{ }^{\circ} \mathrm{C}$ ) without $\mathrm{RuO}_{2}$. Catalyst $(0.3 \mathrm{~g}$ ), an 10 vol\% methanolwater solution; light source, high-pressure mercury lamp (450 W) with $2 \mathrm{M} \mathrm{NaNO}_{2}$ solution as a filtration. Inner irradiation-type reaction vessel. Reaction temperature was controlled between 20 to $25^{\circ} \mathrm{C}$.

\subsection{Photocatalytic activity of $\mathrm{RuO}_{2}$-loaded Ti-In oxy(nitride) composites}

Ti-In oxy(nitride) composites alone exhibited only small photocatalytic activity for hydrogen evolution. However, when loaded with $\mathrm{RuO}_{2}$, the material became much more photocatalytically active. Fig. 5 shows the dependence of visible light activity of different ammonolysis temperatures $\mathrm{RuO}_{2}$-loaded (1 wt\%) Ti-In (oxy)nitride samples in $\mathrm{pH}$ adjusted (sulfuric acid) 10 vol\% methanol-water solution. (In this work, methanol is used 
as a sacrificial agent so that the best condition for the hydrogen evolution step can be ascertained.[18]) The hydrogen production activity was observed at a higher rate. The light source was turned off after $5 \mathrm{~h}$ (Fig. 5), and no hydrogen evolution activity was
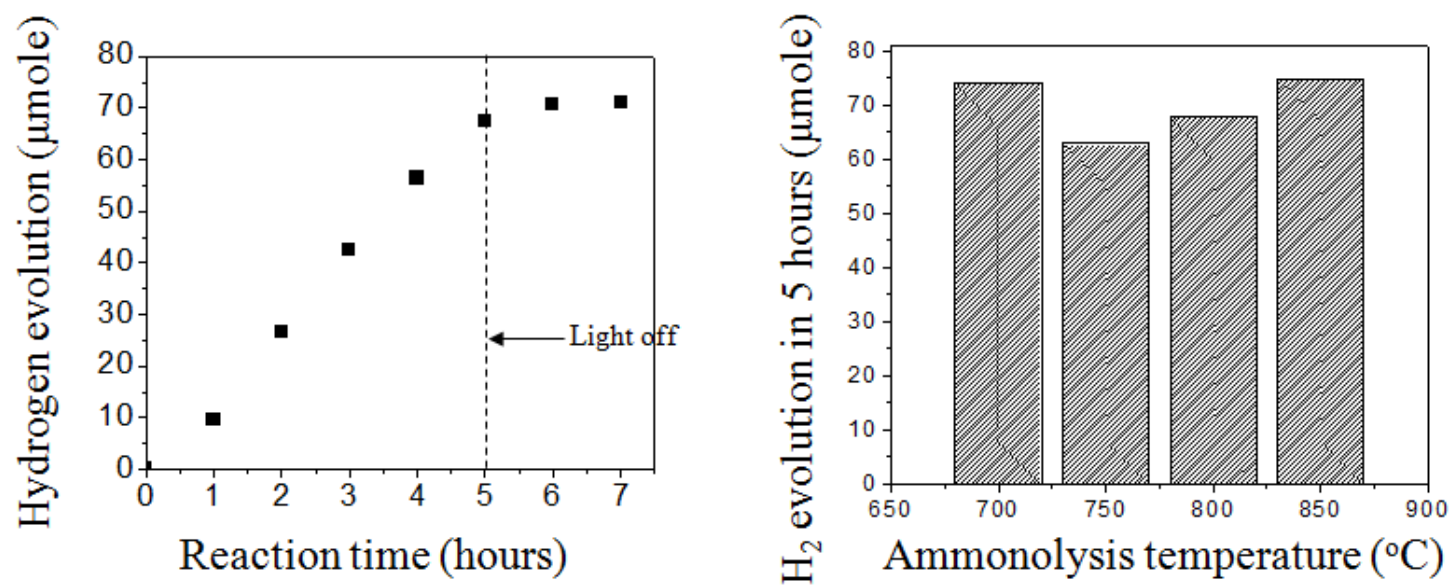

Fig. 5. Dependence of visible light hydrogen production activity of $\mathrm{RuO}_{2}$-loaded ( $1 \mathrm{wt} \%$ ) Ti-In oxy(nitride) composites obtained by different ammonolysis temperatures samples. Catalyst (0.3g), an methanol-water solution (10 vol \%); light source, high-pressure mercury lamp $(450 \mathrm{~W})$ with $2 \mathrm{M} \mathrm{NaNO}_{2}$ solution as a UV light filter. Inner irradiationtype reaction vessel. Reaction temperature was controlled between 20 to $25{ }^{\circ} \mathrm{C}$.

noted, indicating that this is a photo-driven reaction. Moreover, the maximum rate of $\mathrm{H}_{2}$ evolution was $14 \mu$ mole $\cdot \mathrm{h}^{-1}$. The amount of the $\mathrm{RuO}_{2}$-loaded Ti-In oxy(nitride) photocatalyst used contained $22 \mu \mathrm{mol}$ of $\mathrm{RuO}_{2}$. The number of electrons consumed was estimated to be $516 \mu \mathrm{mol}$ judging from the amount of evolved $\mathrm{H}_{2}$. The electron turnover number to amounts of loaded $\mathrm{RuO}_{2}$ reached 23, respectively, after $45 \mathrm{~h}$ of irradiation. Therefore, by this measure it can be concluded that $\mathrm{H}_{2}$ evolution photocatalytically proceeded. 


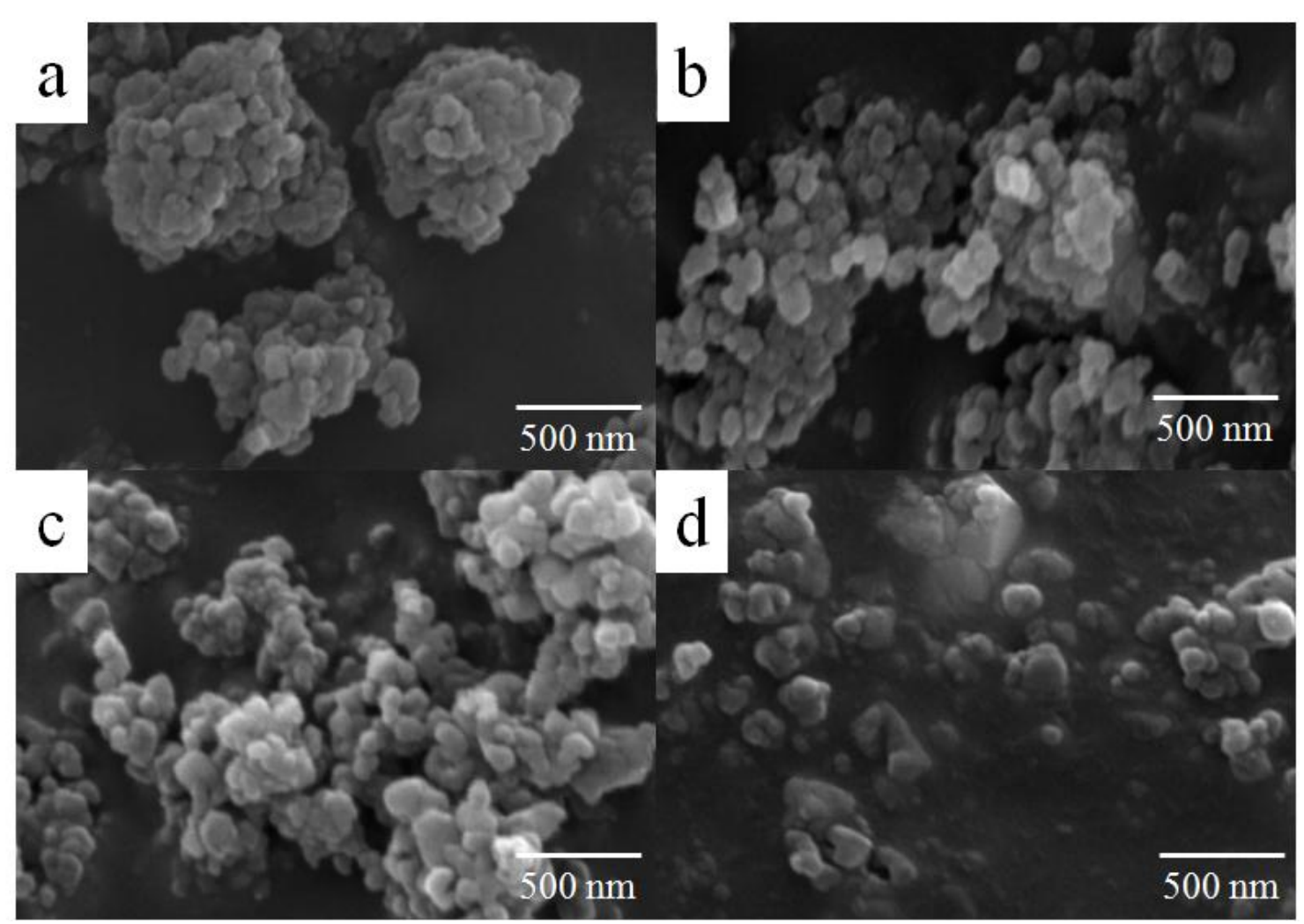

Fig. 6. SEM images of $\mathrm{RuO}_{2}$-loaded (1 wt \%) Ti-In oxy(nitride) composites obtained by different ammonolysis temperatures. (a) $700{ }^{\circ} \mathrm{C}$ (b) $750{ }^{\circ} \mathrm{C}$ (c) $800{ }^{\circ} \mathrm{C}$ (d) $850{ }^{\circ} \mathrm{C}$.

The surface morphologies of $\mathrm{RuO}_{2}$-loaded Ti-In oxy(nitride) composites are presented in

Fig. 6. The average particle size of the individual units of the sample treated at $700{ }^{\circ} \mathrm{C}$ was about $20 \mathrm{~nm}$ (Fig. 7). However, as the treatment temperature increased from 750 to $850{ }^{\circ} \mathrm{C}$, the units began to aggregate and the boundaries between them became increasingly unclear because of growth of the $\mathrm{TiO}_{2}$ (anatase) (Fig. 8, inset). 


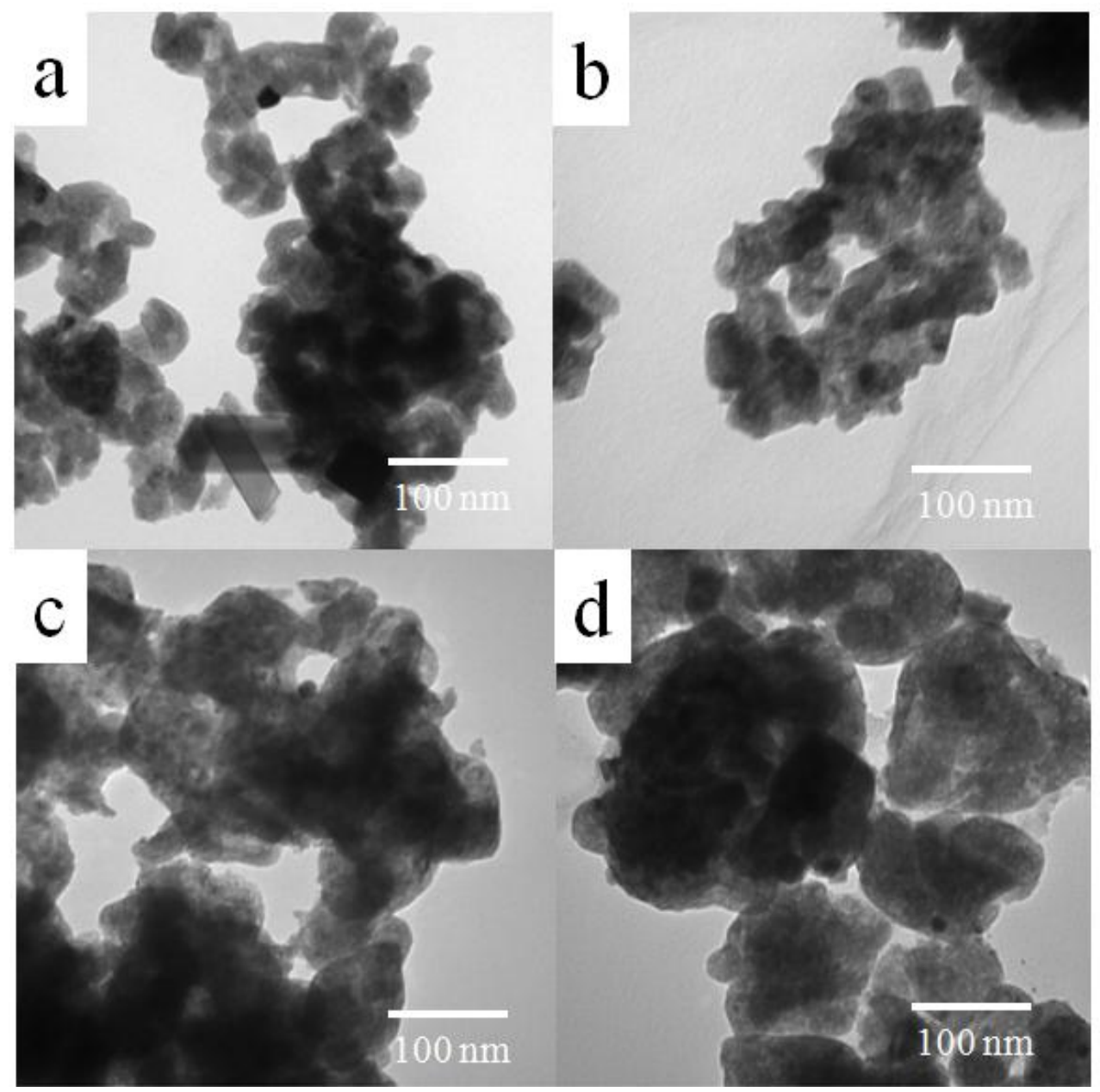

Fig. 7. TEM images of $\mathrm{RuO}_{2}$-loaded (1 wt \%) Ti-In oxy(nitride) composites obtained by different ammonolysis temperatures. (a) $700{ }^{\circ} \mathrm{C}$ (b) $750{ }^{\circ} \mathrm{C}$ (c) $800{ }^{\circ} \mathrm{C}$ (d) $850{ }^{\circ} \mathrm{C}$ 


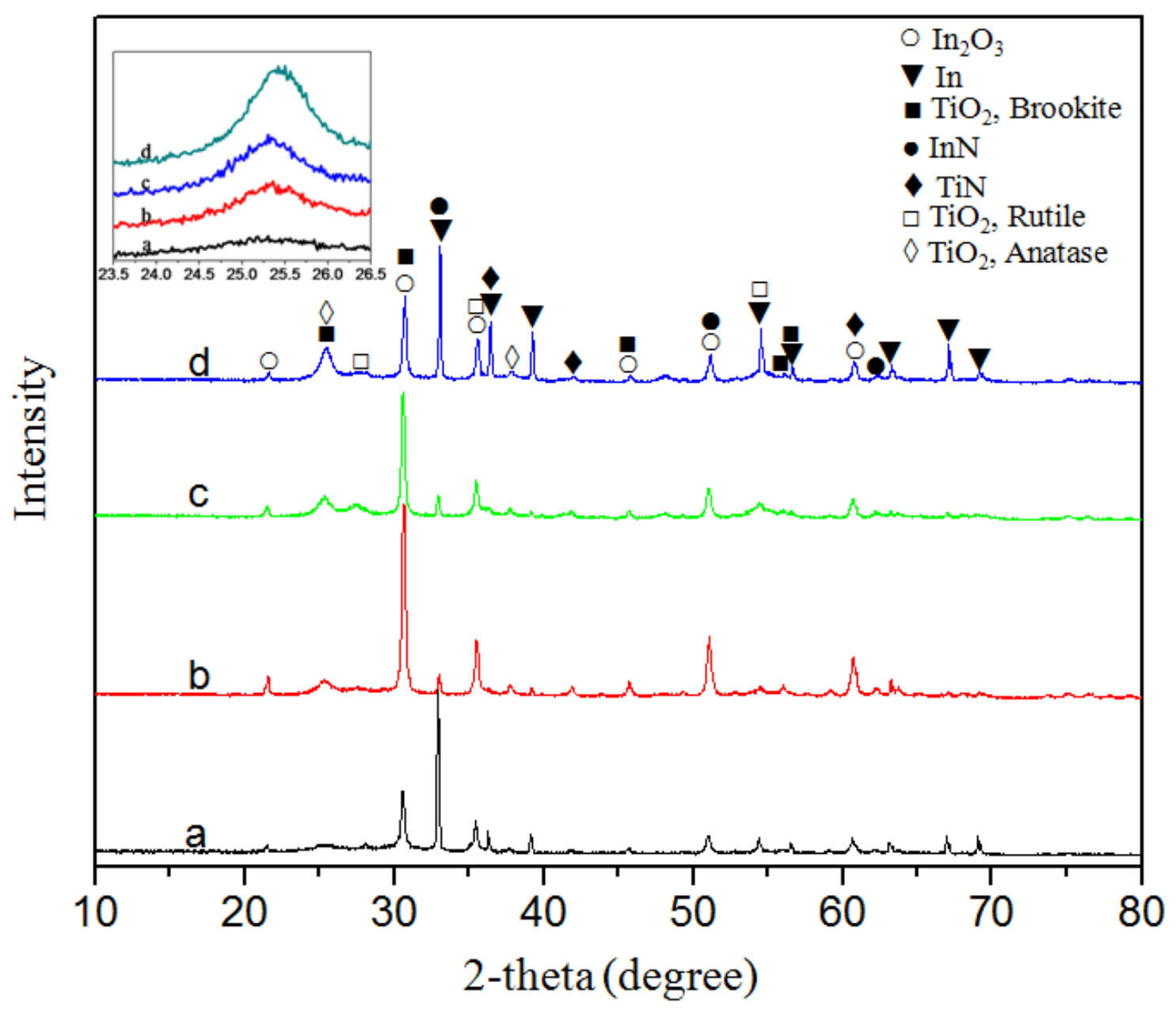

Fig. 8. Powder $\mathrm{XRD}$ patterns of $\mathrm{RuO}_{2}$-loaded ( $1 \mathrm{wt} \%$ ) Ti-In oxy(nitride) composites obtained by different ammonolysis temperatures. (a) $700{ }^{\circ} \mathrm{C}$ (b) $750{ }^{\circ} \mathrm{C}$ (c) $800{ }^{\circ} \mathrm{C}$ (d) 850 ${ }^{\circ} \mathrm{C}$

Table 1 shows the hydrogen production activity of different $\mathrm{RuO}_{2}$-loaded Ti-In oxy(nitride) (ammonolysis at $750{ }^{\circ} \mathrm{C}$ ) composites in $\mathrm{pH}$ adjusted (sulfuric acid) watermethanol under visible light. The photocatalytic activity increased markedly with increasing $\mathrm{RuO}_{2}$ content to a maximum at about $3 \mathrm{wt} \%$, with the activity dropping at higher $\mathrm{RuO}_{2}$ contents. Fig. 9 shows UV-Visible diffuse reflectance spectra for solid composites prepared with different $\mathrm{RuO}_{2}$-loading amounts, and show an increase in 


\section{Table 1}

Photocatalytic activity of different $\mathrm{RuO}_{2}$-loaded Ti-In oxy(nitride) (ammonolysis at 750 ${ }^{\circ} \mathrm{C}$ ) composites and Ti oxy(nitride) under visible light in methanolwater solution (10 vol\%) .

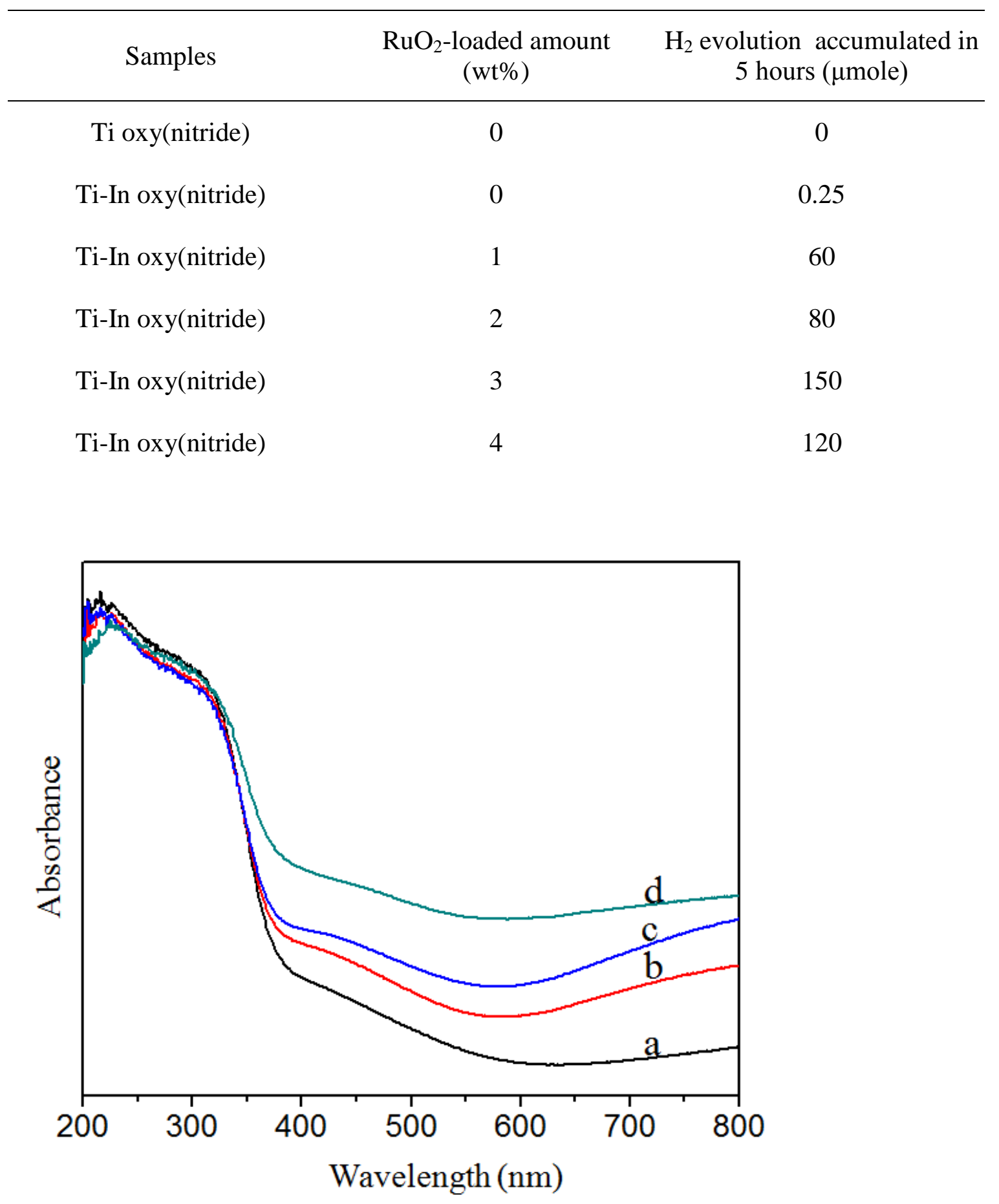

Fig. 9. Diffuse reflectance spectra of samples obtained by different $\mathrm{RuO}_{2}$-loadeded amount Ti-In oxy(nitride) (ammonolysis at $750{ }^{\circ} \mathrm{C}$ ) composites. (a) $1 \mathrm{wt} \% \mathrm{RuO}_{2}$ (b) $2 \mathrm{wt}$ $\% \mathrm{RuO}_{2}$ (c) 3 wt $\% \mathrm{RuO}_{2}$ (d) 4 wt $\% \mathrm{RuO}_{2}$. 
absorbance in the visible region along with the increase of $\mathrm{RuO}_{2}$ loading. Based on UVVisible spectra, the hydrogen production is affected by visible light absorbance: the higher the absorbance, the higher the activity. The decrease in photocatalytic activity with higher $\mathrm{RuO}_{2}$ content indicates that loading with excess $\mathrm{RuO}_{2}$ causes agglomeration and reduces the number density of photocatalytic active sites. Fig. 10 shows the SEM and
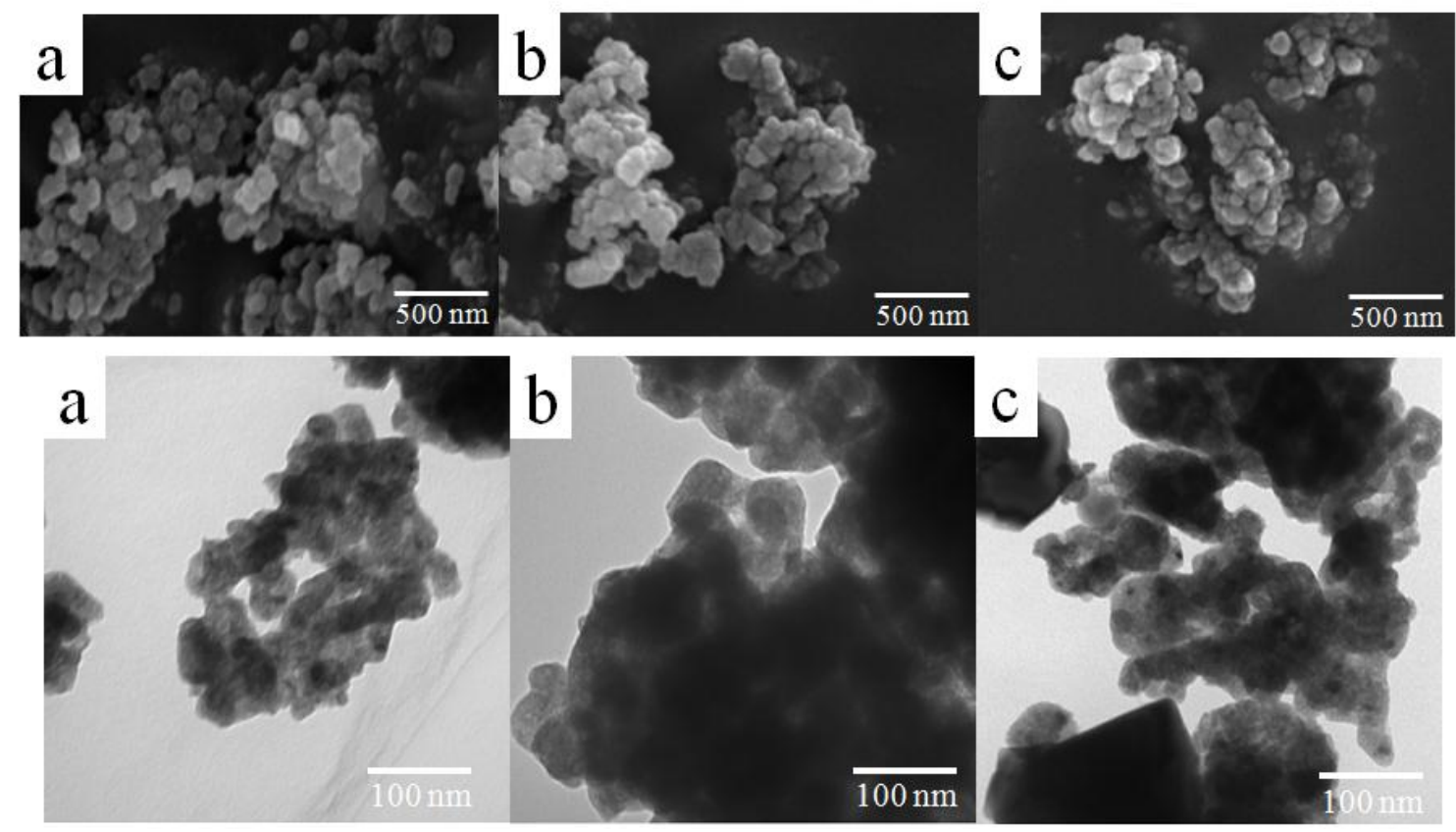

Fig. 10. SEM (up) and TEM (down) images of different $\mathrm{RuO}_{2}$-loadeded amount Ti-In oxy(nitride) (ammonolysis at $750{ }^{\circ} \mathrm{C}$ ) composites. (a) 1 wt $\% \mathrm{RuO}_{2}$ (b) $2 \mathrm{wt} \% \mathrm{RuO}_{2}$ (b) 3 wt $\% \mathrm{RuO}_{2}$.

TEM images of the $\mathrm{RuO}_{2}$-loaded Ti-In oxy(nitride) composites. The surface morphology shows no obvious change during the increase of loaded $\mathrm{RuO}_{2}$. However, TEM images show more dark dots inside the particles due to the agglomeration of excess $\mathrm{RuO}_{2}$. The same tendency has been reported for $\mathrm{RuO}_{2}$-loaded $\left(\mathrm{Ga}_{1-x} \mathrm{Zn}_{\mathrm{x}}\right)\left(\mathrm{N}_{1-x} \mathrm{O}_{\mathrm{x}}\right)$ solid solution[19] and $\left(\mathrm{Zn}_{1+x} \mathrm{Ge}\right)\left(\mathrm{N}_{2} \mathrm{O}_{x}\right)$ Solid Solution[20]. Moreover, the decrease of surface area may due to the agglomeration (Table 2), when the $\mathrm{RuO}_{2}$ loaded amount exceeds $3 \mathrm{wt} \%$. 


\section{Table 2}

Characteristic properties of different $\mathrm{RuO}_{2}$-loaded Ti-In oxy(nitride) (ammonolysis at $750{ }^{\circ} \mathrm{C}$ ) composites.

\begin{tabular}{cccc}
\hline $\begin{array}{c}\mathrm{RuO}_{2} \text {-loaded } \\
\text { amount } \\
(\mathrm{wt} \%)\end{array}$ & $\begin{array}{r}\text { Surface Area } \\
\left(\mathrm{m}^{2} / \mathrm{g}\right)\end{array}$ & $\begin{array}{c}\text { Total pore volume } \\
\left(\mathrm{cm}^{2} / \mathrm{g}\right)\end{array}$ & $\begin{array}{c}\text { Average pore size } \\
(\mathrm{nm})\end{array}$ \\
\hline 1 & 10.4 & 0.22 & 14.5 \\
2 & 13.5 & 0.29 & 14.6 \\
3 & 18.1 & 0.42 & 14.5 \\
4 & 10.7 & 0.23 & 14.5
\end{tabular}

During these experiments there was no $\mathrm{O}_{2}$ evolution observed, even though the potential of generated holes might be thermodynamically high enough for oxidation of water to form $\mathrm{O}_{2}$. However, there are no reaction centers for the four-electron oxidation for $\mathrm{O}_{2}$ evolution. On the other hand, the standard redox potentials for $\mathrm{HCHO} / \mathrm{CH}_{3} \mathrm{OH}$ and $\mathrm{H}_{2} \mathrm{CO}_{3} / \mathrm{CH}_{3} \mathrm{OH}$ are 0.232 and $0.044 \mathrm{~V}$, so methanol oxidation is easy compared to oxidation of water coupled with $\mathrm{O}_{2}$ evolution from water $(1.23 \mathrm{~V})$ from both thermodynamic and kinetic standpoints.[21] Moreover, it is well-known that $\mathrm{O}_{2}$ evolution has a large overpotential $(>0.5 \mathrm{~V}) \cdot[21]$

\section{Conclusions}

Novel $\mathrm{RuO}_{2}$-loaded Ti-In (oxy)nitride composites were prepared by nitridation of $\mathrm{TiO}_{2}$ and $\mathrm{In}_{2} \mathrm{O}_{3}$ under an $\mathrm{NH}_{3}$ flow of $250 \mathrm{~mL} \cdot \mathrm{min}^{-1}$ and loaded with $\mathrm{RuO}_{2}$ by using Ruthenium(III) acetylacetonate as the precursor. The preparation of (oxy)nitride provides a new strategy to synthesize $\mathrm{InN}$ at high temperature $\left(>700{ }^{\circ} \mathrm{C}\right)$. And $\mathrm{Ti}^{4+}$ could be reduced to $3+$ and $2+$ upon ammonia treatment with $\operatorname{In}_{2} \mathrm{O}_{3}$ presence. The change in the 
product with nitridation temperature was examined, and it was revealed that an active mixed nitride/oxide phase formed above $700{ }^{\circ} \mathrm{C}$ of nitridation. However, temperature above $900{ }^{\circ} \mathrm{C}$ caused Indium metal to form, which is volatile at $900{ }^{\circ} \mathrm{C}$ and was lost, resulting in mainly TiN formation, and these samples exhibited no photocatalytic activity. The XRD and XPS spectra confirmed that the prepared powders had nitrogen substituted at some of the oxygen sites in the $\mathrm{TiO}_{2}$ and $\mathrm{In}_{2} \mathrm{O}_{3}$. The UV-Visible diffuse reflectance spectra absorbance in the visible light region varied with $\mathrm{RuO}_{2}$ loaded amount from 1 to $4 \mathrm{wt} \%$, which are directly reflected by different $\mathrm{H}_{2}$ evolution activities, but excess $\mathrm{RuO}_{2}$ may reduce the number density of photocatalytic active sites resulting a lower performance. The optimum preparation conditions for $\mathrm{RuO}_{2}$-loaded Ti-In (oxy)nitride in order to achieve high hydrogen evolution are thus considered to be nitridation between

700 to $850{ }^{\circ} \mathrm{C}$ under $\mathrm{NH}_{3}$ flow at $250 \mathrm{~mL} \cdot \mathrm{min}^{-1}$ and loaded with 3 wt\% $\mathrm{RuO}_{2}$. The composite produced under these conditions minimizes Indium loss by reduction to Indium metal and subsequent volatilization, but some Indium is retained as $\mathrm{InN}$ that is stabilized in the structure, and is important in hydrogen production. And the $3 \mathrm{wt} \% \mathrm{RuO}_{2}$ loaded amount gave the optimum balance between reaction sites and aggregation.

\section{Acknowledgments}

Support from the National Science Foundation EPSCoR Renewable Energy Project, NanoScale Corporation and M2 Corporation are acknowledged with gratitude. 


\section{References}

[1] F.E. Osterloh, Chemistry of Materials, 20 (2007) 35.

[2] J. Sato, N. Saito, Y. Yamada, K. Maeda, T. Takata, J.N. Kondo, M. Hara, H. Kobayashi, K. Domen and Y. Inoue, Journal of the American Chemical Society, 127 (2005) 4150.

[3] K. Maeda, T. Takata, M. Hara, N. Saito, Y. Inoue, H. Kobayashi and K. Domen, Journal of the American Chemical Society, 127 (2005) 8286.

[4] H. Irie, Y. Watanabe and K. Hashimoto, Journal of Physical Chemistry B, 107 (2003) 5483.

[5] R. Asahi, T. Morikawa, T. Ohwaki, K. Aoki and Y. Taga, Science, 293 (2001) 269.

[6] S.K. Poznyak, D.V. Talapin and A.I. Kulak, The Journal of Physical Chemistry B, 105 (2001) 4816.

[7] K.R. Reyes-Gil, E.A. Reyes-Garcia and D. Raftery, Journal of Physical Chemistry C, 111 (2007) 14579.

[8] Y.T. Kuo and K.J. Klabunde, Appl. Catal. B-Environ., 104 (2011) 245.

[9] B. Schwenzer, L. Loeffler, R. Seshadri, S. Keller, F.F. Lange, S.P. DenBaars and U.K. Mishra, Journal of Materials Chemistry, 14 (2004) 637.

[10] J. Trainor and K. Rose, Journal of Electronic Materials, 3 (1974) 821.

[11] Q. Guo, O. Kato and A. Yoshida, Journal of Applied Physics, 73 (1993) 7969.

[12] H. Idriss, K.G. Pierce and M.A. Barteau, Journal of the American Chemical Society, 116 (1994) 3063.

[13] T. Maruyama, K. Yorozu, T. Noguchi, Y. Seki, Y. Saito, T. Araki and Y. Nanishi, physica status solidi (c), 0 (2003) 2031.

[14] C. Donley, D. Dunphy, D. Paine, C. Carter, K. Nebesny, P. Lee, D. Alloway and N.R. Armstrong, Langmuir, 18 (2002) 450.

[15] N. Asai, Y. Inoue, H. Sugimura and O. Takai, Journal of The Electrochemical Society, 146 (1999) 2365.

[16] X. Chen and C. Burda, The Journal of Physical Chemistry B, 108 (2004) 15446.

[17] T. Sano, N. Negishi, K. Koike, K. Takeuchi and S. Matsuzawa, Journal of Materials Chemistry, 14 (2004) 380.

[18] A. Kudo and Y. Miseki, Chemical Society Reviews, 38 (2009) 253.

[19] K. Teramura, K. Maeda, T. Saito, T. Takata, N. Saito, Y. Inoue and K. Domen, The Journal of Physical Chemistry B, 109 (2005) 21915.

[20] Y. Lee, H. Terashima, Y. Shimodaira, K. Teramura, M. Hara, H. Kobayashi, K. Domen and M. Yashima, The Journal of Physical Chemistry C, 111 (2007) 1042.

[21] Y. Sasaki, H. Nemoto, K. Saito and A. Kudo, The Journal of Physical Chemistry C, 113 (2009) 17536. 